\title{
Julie M. Parsons (2015), Gender, Class and Food: Families, Bodies and Health, London, Palgrave Macmillan ${ }^{1}$
}

\section{Review by Joana Caetano}

University of Porto - ALIMENTOPIA / Utopian Foodways Project

The field of Food Studies has been a focus of increasing interest among the scientific community; evidence of that is the exponential number of publications within the field in the last years. Collections of essays on Food and Literature, Food and Film, Food and History, Food and Utopia, ${ }^{2}$ among other topics, have been edited, and intersectional research bridging the study of food and its many implications in specific contexts has brought up rather thought-provoking conclusions. Already in 1998, Carole M. Counihan, in collaboration with Steven L. Kaplan, edited Food and Gender: Identity and Power, a collection of essays that, in a whole, demonstrate how foodways can be an efficient filter to comprehend economical and socio-political systems. Also Arlene V. Avakian and Barbara Haber, in their introduction to From Betty Crocker to Feminist Food Studies: Critical Perspectives on Women and Food (2005), resorting to Feminist Studies, present an intersectional approach to food to unveil gender and race markers of differentiation. Within this framework, the intersectional research done in Gender, Class and Food: Families, Bodies and Health (2015) comes up as a worthy addition to the field of Food Studies.

Julie Parsons, an Associate Professor in Sociology at the University of Plymouth, published this volume as the result of the research done during her PhD. As she claims in 
the "Introduction" to the volume (Chapter 1), her research has led her to argue that "everyday foodways enable individuals to present themselves as responsible neo-liberal citizens, so that for example eating healthily demonstrates an engagement with public and medical discourses that positions the self as responsible for their own health and wellbeing" (1). Consequently, she acknowledges and emphasises the power of everyday foodways in creating identities and in maintaining and reinforcing social divisions along the lines of gender and class in the United Kingdom.

The analysis of autobiographical food narratives provided by 75 respondents leads Parsons to believe that everyday foodways have become a potent means of 'doing gender' and performing a middle class habitus. Foodways, she explains, usually refer to the production and distribution of food at a macro level and are also used in Anthropology when exploring food cultures or shared common beliefs, behaviours and practices relating to the production and consumption of food. For Parsons, foodways may also be considered at a micro level, to reflect the multiplicity of ways of 'doing' food that incorporates all aspects of everyday food practices, from acquiring food, growing it, or shopping for it, preparing, cooking, sharing and eating, to the consumption of food media. This means that the notion of foodways incorporates also an essential aspect of an individual's identity and cultural habitus, which is cultivated and inculcated over time (1-3). They are ongoing emotional, socially constructed, embodied, situated performances infused with sedimented social and personal history (and, I might add, prejudices). Furthermore, Parsons claims, “'foodways' has multiple meanings; it highlights the significance of modes of practice or ways of 'doing' food, as well as movement and direction across time (history) and space (culture). Consequently, foodways connect the individual with the social through everyday practices (action/habit)" (1-2).

Like gender and class, Parsons clarifies that foodways work within three interconnecting domains:

(i) on an 'individual' level, through socialisation, internalisation, identity work and the construction of the self; 
(ii) through interactional 'cultural' expectations and 'othering' of practices; and

(iii) via 'institutions' that control access to resources, as well as ideologies and discourses (2).

This means that performances of everyday foodways are validated, constrained and facilitated by reference to wider institutional contexts that may include gender (patriarchy), class (economics), culture (capital) and 'the' family (discourse). Therefore, contrary to popular belief, foodways are not a matter of 'choice', of choosing the healthiest diet. Indeed, Parsons' research leads her to defy the notion that individuals make food choices free from wider structural constraints.

In order to prove this argument, Parsons organizes the volume in five thematic areas: Family Foodways, Maternal Foodways, Health Foodways, Embodied Foodways and Epicurean Foodways.

In Chapter 2, "Family Foodways", Parsons focuses on how food acts as a marker of culinary capital in the family and how women are positioned as the main responsible agent in daily domestic foodwork, contrary to men whose majority only cook for pleasure. Chapter 3, "Maternal Foodways", exposes how healthy homecooked meals are perceived as high cultural capital, in the sense that, mothers feel pressured to prepare meals from scratch as a sign of care and love. Indeed, according to the respondents' narratives, it appears that when mothers give mass-produced or processed food to their children, they are marginalised and stigmatised as irresponsible. Fathers seem to feel no such pressure.

Chapter 4 on "Health Foodways" and 5 on "Embodied Foodways" are to some extent interconnected, since they both lead to the conclusion that women are more predisposed to follow a strict diet either for health reasons or aesthetic concerns. Hence, health and embodied foodways are coded as feminine. In the case of women, following a healthy rigid diet is perceived as an expression of elite cultural capital, due to its connotation to selfdiscipline, while for men cultural capital is associated with gourmet practices such as dining out, eating meat and exotic food.

The chapter on "Epicurean Foodways" explores how food enthusiasts can take sensual pleasure in eating 'good' food. Mainly male respondents' narratives form this 
chapter. Parsons claims that, due to strict 'rules' of domestic and maternal foodways, women seem hardly able to engage in epicurean foodways, since these are associated with competition and adventurousness, features mostly coded as masculine (136).

To analyse her data and connect respondents' narratives to their socio-cultural contexts, Parsons resorts to a vast theoretical apparatus namely theories from Counihan, Bordo, Naccarato \& Lebesco, Johnston \& Baumann.

Parsons concludes the volume highlighting the power of everyday foodways as a marker of social differentiation, and class and gender distinction. The respondents' narratives seem to position women as primarily responsible for the nourishment and nurturing of children and therefore society, as part of a natural order. They suggest that there are identifiable cultural codes, rules and rituals around everyday foodways; and that 'proper' foodways can be located in diametric opposition to the quick, cheap, massproduced meals. People who fail to follow the cultural codes and rules, for lack of knowledge or resources, are stigmatised, especially women and particularly mothers. Therefore, the author states, "whilst individuals are supposedly free to make rational choices, it is apparent that gender and class bind them. This proves the interconnectedness of the individual and the social, the micro and the macro, the private and the public" (163).

Although this study has presented useful data denouncing the constraints in eating habits due to questions of class and gender, in my opinion, there are some issues in the study's execution that may weaken the scientific conclusions. Firstly, the method to collect data may has excluded possible interviewees that are not comfortable engaging in written dialogue with an academic. Particularly when specific software is involved, it may alienate some demographic groups. Secondly, the sample seems to be too small (75 respondents to map the eating habits of the entire UK seem hardly conclusive). Even Parsons admits that, as for the demographics, she did not have any accounts from people between the ages of 1835 (168). Furthermore, it seems to include mainly middle-class (possibly white) female respondents. In a study that aims to provide an intersectional approach to class and gender, that is problematic. 
Julie M. Parsons (2015), Gender, Class and Food: Families, Bodies and Health, London, Palgrave Macmillan

Despite these issues, Gender, Class and Food: Families, Bodies and Health is definitely worth the read. It raises pertinent questions regarding everyday foodways that are so embedded in social behaviour that seem hardily questionable. It can be the starting point to "a conversation in progress", as Alexandra Rodney puts it, and it is undoubtedly a valuable contribution to the field of Food Studies.

\section{NOTES}

1 The present work was carried out within the framework of the ALIMENTOPIA / Utopian Foodways Project, financed by the FEDER Funds through the Competitiveness and Internationalization Operational Programme COMPETE 2020 and by Portuguese National Funds through FCT - the Portuguese Foundation for Science and Technology (PTDC / CPC-ELT / 5676/2014 POCI-01-0145-FEDER-016680).

2 Some relevant titles published in the field are: Food and Cultural Studies. (2004) by Ashley et al.; Bordo's Unbearable Weight: Feminism, Western Culture, and the Body (2003); Nyman and Gallardo's Mapping Appetite: Essays on Food, Fiction and Culture (2007); Sceats' Food, Consumption and the Body in Contemporary Women's Fiction (2003); and Food Utopias: Reimagining Citizenship, Ethics, and Community (2015) by Stock et al. 


\section{Works Cited}

Ashley, Bob, Joanne Hollows, Steve Jones and Ben Taylor (2004), Food and Cultural Studies, UK, Routledge.

Avakian, Arlene Voski /Barbara Haber (ed.) (2005), From Betty Crocker to Feminist Food Studies: Critical Perspectives on Women and Food, USA, University of Massachusetts Press.

Bordo, Susan (2003), Unbearable Weight: Feminism, Western Culture, and the Body, California, University of California Press [1993].

Counihan, Carole M. / Steven L. Kaplan (ed.) (2005), Food and Gender: Identity and Power, Amsterdam, Harwood Academic Publishers [1998].

Nyman, Jopi / Pere Gallardo (2007), Mapping Appetite: Essays on Food, Fiction and Culture, UK, Cambridge Scholars Publishing.

Rodney, Alexandra (2017), Review of Gender, Class and Food, gradfoodstudies, March 1, Review, vol. 4, no. 1, < https://gradfoodstudies.org/2017/03/01/review-gender-class-andfood/>

Sceats, Sarah (2003), Food, Consumption and the Body in Contemporary Women's Fiction, Cambridge, Cambridge University Press [2000].

Stock, Paul V. / Michael Carolan / Christopher Rosinr (2015), Food Utopias: Reimagining Citizenship, Ethics, and Community, UK, Routledge. 